FACTA UNIVERSITATIS

Series: Physical Education and Sport, Vol. 18, No 2, 2020, pp. 305 - 310

https://doi.org/10.22190/FUPES200520028S

Professional article

\title{
EDUCATIVE ASPECTS OF DOPING PREVENTION IN SCHOOL-AGED CHILDREN AND ADOLESCENTS
}

\author{
UDC 796.011.5:178 \\ 796-053.2
}

\section{Emilija Stojanović, Dragan Radovanović}

Faculty of Sport and Physical Education, University of Niš, Niš, Serbia

\begin{abstract}
The aim of this study was to provide an overview of doping prevention strategies in school-aged children and adolescents. To preserve the spirit of sport, the Anti-Doping Code requires that each anti-doping organization should develop and implement education and prevention programs for athletes, including the young and support staff. Education programs that encourage respect, equity, and inclusion, are closely related to fairness and should be implemented in school-aged children. The focus on school-aged children is essential, since early adolescence is a critical stage associated with a distorted body image (muscle dysmorphia), which in turn can lead to deliberate use of prohibited substances (mostly androgenic anabolic steroids) or methods. Since adolescents are focused on the "here" and "now", the conception of anti-doping programs should emphasize the adverse effects of doping at the early stage of use, as well as a high probability of health consequences. Encouraging prevention should raise awareness of the recipients about adverse effects, which in turn should produce anti-doping behavior. Moreover, the goal of preventive actions should be the development of self-esteem, which equals the observance of rights and values of other people, and the ability to refuse through the strategy termed "A way to say: No".
\end{abstract}

Key words: Sports, Prohibited Substances and Methods, Anti-Doping Programs

\section{INTRODUCTION}

Anti-doping programs are implemented with the aim to preserve the essential value of sport. That essential value is often termed "the spirit of sport" and it represents the bedrock of Olympism (International Olympic Committee, 2012). Doping is fundamentally opposed to the spirit of sport. To preserve the spirit of sport, the Anti-Doping Code requires that each antidoping organization should develop and implement education and prevention programs for athletes, including the young and support staff (United Nations Educational Scientific and

Received May 20, 2020 / Accepted July 21, 2020

Corresponding author: Emilija Stojanović

Faculty of Sport and Physical Education, University of Niš, Čarnojevića 10a, 18000 Niš, Serbia

Phone: + 38118510900 •E-mail: stojanovic.emilija@yahoo.com

ㄷ 2020 by University of Niš, Serbia | Creative Commons License: CC BY-NC-ND 
Cultural Organization-UNESCO, World Anti Doping Agency-WADA, Olympic Foundation for Culture and Heritage, International Council of Sport Science and Physical Education, \& Foundation-ICSSPE, 2019). The objective of information and education anti-doping programs is to prevent the use of prohibited substances and prohibited methods in sports. The focus of information programs should be oriented towards providing fundamental information to athletes, including updated and accurate information on substances and methods on the Prohibited List, anti-doping rule violations, consequences of doping, doping control procedures, athletes' and athlete support staff's rights and responsibilities (WADA, 2019). Education programs should be directed towards athletes and support staff, with special attention paid to the approach to young people through school programs (WADA, 2020). Prevention programs should be oriented primarily towards young individuals, and should be appropriately conceived to match their age, schools, sports clubs, parents, adult athletes, sports officials, coaches, medical support staff, and the media.

The aim of this study was to provide an overview of doping prevention strategies in school-aged children and adolescents. Theoretical considerations of the problem.

\section{THEORETICAL CONSIDERATIONS OF THE PROBLEM}

\section{Prevention among school-aged children}

The leading international partner organizations initiated a number of activities in 2019 under the common name "Sport values in every classroom", directed towards children aged 8 to 12 years (UNESCO et al., 2019). The aim of this global campaign was to instill the values of respect, equity and inclusion in school-aged children.

Respect involves acceptance of the customs and cultures which differ from one's own; accepting someone or something without attempting to change or harm it; and showing politeness, honour, and care for someone or something. In line with this, activities address attitudes and behaviors that should foster dignity, care for oneself and others, and encouragement of thinking about emotions, ethical (moral) dilemmas, as well as rights and duties (UNESCO et al., 2019).

Equity in sports refers to an equal approach, recognition of inequity and taking steps to resolve it. Equity requires continual cultural and structural changes in sport, ensuring equal accessibility to all members of a society, regardless of their age, ability, gender, race, ethnic background, sexual orientation, or socioeconomic status (Lyras \& Hums, 2009). Equity activities foster openness to different people and things, and overcome prejudice, moving forward in the understanding and acceptance that all people are equal. Such activities promote equality of opportunity to all people, allowing them to fulfill their potentials and understand the importance of the concept of equal opportunities for all.

Inclusion is closely associated with righteousness. Both these values act towards overcoming differences, insisting upon equal rights for all, regardless of individual characteristics. Collectively, education programs that encourage respect, equity, and inclusion are closely related with fairness and should be implemented among school-aged children.

\section{Prevention in adolescence}

Adolescence is a period of transition from immaturity of childhood to maturity of adulthood. It starts with the first signs of puberty, and is completed when a person reaches an 
appropriate level of maturity and independence (Kipke, 1999). During adolescence, numerous physiological, cognitive, social and emotional changes occur; these changes are individual and that is the reason why adolescence cannot be clearly delineated - it may last from the age of 11 or 12 , to the age of 20 or even 25 . Adolescence and puberty are not synonymous, since puberty refers to physical and physiological changes associated primarily with the development of reproductive functions under the influence of hormones (Galvan, 2017).

Adolescence is a critical stage associated with a distorted body image, which in turn can lead to deliberate use of prohibited substances [mostly androgenic anabolic steroids (AAS)] or methods. AAS, synthetic derivatives of the male hormone testosterone are among the most commonly used drugs by amateur and recreational (non-competitive at the international or national level), adolescent athletes who suffer from muscle dysmorphia (Cerea, Bottesi, Pacelli, Paoli, \& Ghisi, 2018). Muscle dysmorphia is a pathological condition in which an individual believes that one's body is not sufficiently muscular, that it is smaller or weaker than it objectively is. Even an insignificant loss of muscle mass is very difficult to accept by individuals with muscle dysmorphia. Furthermore, Baker et al. (2019) have noted that muscle dissatisfaction is greater than height dissatisfaction. The users follow dosage regimens involving different AAS, their combinations, but also other pharmaceutical substances for which they believe can supplement the desired effects upon their skeletal muscles or to reduce adverse effects (Mullen, Whalley, Schifano, \& Baker, 2020). Although AAS misuse is often used to manage muscle dysmorphia, recent evidence suggests (Jampel, Murray, Griffiths, \& Blashill, 2016) that boys who perceive themselves as overweight may also be at risk for AAS misuse, with the aim to reduce their fat mass and preserve or increase lean body mass. Growing evidence suggests that AAS users develop dependence syndrome (around 30\%), involving constant use of these substances despite the occurrence of adverse effects (Kanayama, Brower, Wood, Hudson, \& Pope Jr, 2009).

A lack of self-esteem and a distorted body image increase the probability of AAS misuse in order to achieve the desired outward appearance as fast as possible (Mitić \& Radovanović, 2011; Griffiths, Jacka, Degenhardt, Murray, \& Larance, 2018). In addition, a lack of social intelligence and/or teasing by their adolescent peers may underpin the increased risk of AAS misuse. In that case, a person undertakes all the steps to enhance physical appearance, including doping, and upon that forms their personality and functioning. As a result, athletes compensate for low self-esteem with their physical appearance. Long-term use or excessive doses of AAS, or other performance enhancing drugs, may produce health risks (Kersey et al., 2012), requiring drug withdrawal and consequent loss of muscle mass. Since muscle mass is the bedrock of psychological functioning in dependent users and in view that psychosocial competences have not been developed to face life outside the training room, serious psychological crises may occur. Psychological treatments are essential in order to prevent or treat depressive disorders and suicidal thoughts occurring after the loss of that false support of personal functioning. Adolescents with depression are in six times greater risk of substance abuse compared to healthy peers (Costello, Egger, \& Angold, 2005 in Grujičić \& Pejović Milovančević, 2019).

The probability that amateur and recreational (non-competitive at the international or national level) adolescent athletes will misuse performance-enhancing drugs is greater if there is an opinion that: 1) the consequences of doping occur only rarely and only for some individuals, 2) the adverse effects occur only after several years of doping, 3) the adverse effects of doping disappear soon after the cessation of doping, 4) physical and psychic consequences are not so serious, and 5) that doping-related warnings are exaggerated. 
Therefore, the conception of anti-doping programs oriented towards adolescents should emphasize the adverse effects of doping at early stage of use (since adolescents are focused on the "here" and "now"), as well as the high probability of health consequences (Mitic \& Radovanović, 2011). Encouraging prevention should raise awareness of the recipient about the adverse effects, which in turn may produce anti-doping behaviour (Donovan, Egger, Kapernick, \& Mendoza, 2002). The information about the harmful effects of doping substances should be as flexible (tailored to fit the target population: risk factors, developmental stage) and vivid as possible, with most striking examples of the doping practices (Backhouse, Patterson, \& McKenna, 2012). Adolescents should be adequately warned about all possible consequences of doping, using adequate photographs and video material and, if feasible, engaging individuals readily recognized by adolescents from the media or the like.

Doping in sport is a widespread problem not only in amateur and recreational adolescent athletes, but also among athletes in the transition to official competitive levels (national or international). That is the reason why during training sessions priority should not be given to winning at all costs; instead, the conditions and environment should be created for the adolescent to develop properly in the physical, psychological and social sense. Certain psychological factors in an individual definitely have a significant impact on the probability of use of doping substances. One of these is fear of failure, manifested as the constant anxiety of a person that they will fall short of one's own and other people's expectations. Fear of failure in adolescents is often a combination of stress, anxiety and perfectionism (Gustafsson, Sagar, \& Stenling, 2017). In this context, perfectionism implies that a person is often unable to discriminate between real and idealized standards. Another factor is low self-esteem, reflected in a doubt in one's own abilities, which a person tries to overcome by a desired outward appearance and aggressivity. The third factor is denoted as the "superman complex", and it involves an adventuristic understanding of doping, with an exaggerated underestimation of the long-term adverse effects of doping. The presence of the factor can often be heard in statements such as "I will only try it", "it is not that harmful", "adverse effects may not occur in my case". Professors of physical education and coaches should have special training to be able to recognize behavioral symptoms in their students or clients as potential users of doping substances. The most common symptoms in adolescent users of doping substances are frequent mood changes, excessive physical training, obsession with dieting, rapid increase in physical abilities, total body mass and muscle mass, aggressivity and various risk behaviors (Mitić \& Radovanović, 2013).

\section{CONCLUSION}

In the last three decades, the use of doping substances by adolescent athletes (recreational, amateur, in the transition to official competitive levels) has become a widespread problem. Since the use of doping frequently starts in the period of early adolescence, school-based doping prevention programs should be introduced. All the adverse effects of doping on physical and psychological health should be explained in detail in a flexible, vivid and concrete way, stressing the seriousness and long-lasting nature of these effects. The goal of preventive actions should be the development of self-esteem, which equals the observance of rights and values of other people, and the ability to refuse through the strategy termed "A way to say: No". 


\section{REFERENCES}

Backhouse, S.H., Patterson, L., \& McKenna, J. (2012). Achieving the Olympic ideal: Preventing doping in sport. Performance Enhancement and Health, 1(2), 83-85.

Baker, J.H., Higgins Neyland, M., Thornton, L.M., Runfola, C.D., Larsson, H., Lichtenstein, P., et al. (2019). Body dissatisfaction in adolescent boys. Developmental Psychology, 55(7), 1566-1578.

Cerea, S., Bottesi, G., Pacelli, Q.F., Paoli, A., \& Ghisi, M. (2018). Muscle dysmorphia and its associated psychological features in three groups of recreational athletes. Scientific Reports, 8(1), 1-8.

Costello, E.J., Egger, H., \& Angold, A. (2005). 10-year research update review: the epidemiology of child and adolescent psychiatric disorders: I. Methods and public health burden. Journal of the American Academy of Child and Adolescent Psychiatry, 44(10), 972-986.

Donovan, R.J., Egger, G., Kapernick, V., \& Mendoza, J. (2002). A conceptual framework for achieving performance enhancing drug compliance in sport. Sports Medicine, 32(4), 269-284.

Galvan, A. (2017). The neuroscience of adolescence. USA: Cambridge University Press.

Griffiths, S., Jacka, B., Degenhardt, L., Murray, S.B., \& Larance, B. (2018). Physical appearance concerns are uniquely associated with the severity of steroid dependence and depression in anabolic-androgenic steroid users. Drug and Alcohol Review, 37(5), 664-670.

Grujičić, R., \& Pejović Milovančević, M. (2019). Intervencije kod dece i mladih sa depresijom (Interventions in children with depressive disorder). Preventivna pedijatrija, 6(1-2). In Serbian

Gustafsson, H., Sagar, S.S., \& Stenling, A. (2017). Fear of failure, psychological stress, and burnout among adolescent athletes competing in high level sport. Scandinavian Journal of Medicine and Science in Sports, 27(12), 2091-2102.

International Olympic Committee (2012). Olympism and the Olympic movement. Retrieved April 27, 2020 from: https://stillmed.olympic.org/media/Document\%20Library/OlympicOrg/Documents/Document-SetTeachers-The-Main-Olympic-Topics/Olympism-and-the-Olympic-Movement.pdf

Jampel, J.D., Murray, S. B., Griffiths, S., \& Blashill, A.J. (2016). Self-perceived weight and anabolic steroid misuse among US adolescent boys. Journal of Adolescent Health, 58(4), 397-402.

Kanayama, G., Brower, K.J., Wood, R. I., Hudson, J.I., \& Pope Jr, H.G. (2009). Anabolic-androgenic steroid dependence: an emerging disorder. Addiction, 104(12), 1966-1978.

Kersey, R.D., Elliot, D.L., Goldberg, L., Kanayama, G., Leone, J.E., Pavlovich, M., et al. (2012). National Athletic Trainers' Association position statement: Anabolic-androgenic steroids. Journal of Athletic Training, 47(5), 567-588.

Kipke, M.D. (1999). Adolescent development and the biology of puberty. In: B. Fischhoff, N.A. Crowell, \& M. Kipke (Eds.), Decision adolescent making-Implications for prevention programs. Summary of a Workshop on New Research. Washington, DC: National Academy Press.

Lyras, A., \& Hums, M.A. (2009). Sport and social change: The case for gender equality. Journal of Physical Education, Recreation and Dance, 80(1), 7-21.

Mitić, P., \& Radovanović, D. (2011). The motives for doping drug use in nonprofessional athletes and methods of prevention. Facta Universitatis Series Physical Education and Sport, 9(2), 203-212.

Mitić, P., \& Radovanović, D. (2013). Abuse of anabolic-androgenic steroids - the problem of sport and society. TEME: Časopis za Društvene Nauke, 37(2), 867-880.

Mullen, C., Whalley, B.J., Schifano, F., \& Baker, J.S. (2020). Anabolic androgenic steroid abuse in the United Kingdom: An update. British Journal of Pharmacology, 177(10), 2180-2198.

United Nations Educational Scientific and Cultural Organization, World Anti Doping Agency, Olympic Foundation for Culture and Heritage, International Council of Sport Science and Physical Education, \& Foundation. (2019). Teaching respect, equity and inclusion to 8-12 year-old students. Retrieved April 22, 2020 from: https://unesdoc.unesco.org/ark:/48223/pf0000371303. locale=en

World Anti-Doping Agency (2019). The World Anti-Doping Code 2015 with 2019 amendments. Retrieved April 15, 2020 from the World Wide Web: https://www.wada-ama.org/sites/default/files/resources/ files/wada_anti-doping_code_2019_english_final_revised_v1_linked.pdf

World Anti-Doping Agency (2020). World Anti-Doping Code, Internatinal Standard, Education. Retrieved May 02, 2020 from the World Wide Web: https://www.wada-ama.org/sites/default/files/resources/files/ 2021_ise.pdf 


\section{EDUKATIVNI ASPEKTI DOPING PREVENCIJE KOD DECE ŠKOLSKOG UZRASTA I ADOLESCENATA}

Cilj ovog rada bio je da pruži pregled strategija prevencije dopinga kod dece i adolescenata. Da bi se očuvao sportski duh, Antidoping kodeks zahteva da svaka andidoping organizacija razvija $i$ implementira edukativne i preventivne programe za sportiste, mlade i pomoćno osoblje. Edukativni programi koji podstiču poštovanje, jednakost $i$ inkluziju usko su povezani sa pravednošću i trebalo bi ih implementirati kod dece školskog uzrasta. Usredsređenost na decu školskog uzrasta je od suštinskog značaja, budući da je rana adolescencija kritična faza povezana sa iskrivljenom slikom telesnog izgleda (mišićnom dismorfijom), što može dovesti do namerne upotrebe zabranjenih supstanci (najčešče androgenih anaboličkih steroida) $i$ metoda. Obzirom da su adolescenti fokusirani na "ovde" $i$ "sada", koncenpcija antidoping programa treba naglasiti da štetne posledice nastaju vrlo brzo nakon početka korišćenja doping supstanci $i$ da je verovatnoća javljanja štetnih posledica po zdravlje velika. Podsticanje prevencije treba da podigne svest o štetnim efektima, tako da se oni teže odluče za njihovu upotrebu. Takođe, cilj preventivnog delovanja treba da bude na razvoju samopoštovanja, koje je jednako poštovanju prava i vrednosti druge osobe, kao i sposobnosti odbijanja kroz tzv. strategiju „,način da se kaže: $N e^{\prime \prime}$.

Ključne reči: sport, zabranjene supstance i metode, antidoping programi 